\title{
Medium-Chain Length Fatty Acids Enhance A $\beta$ Degradation by Affecting Insulin-Degrading Enzyme
}

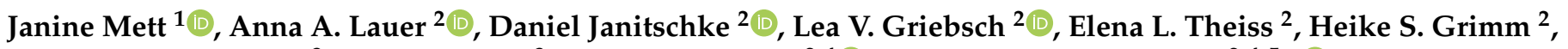 \\ Hennariikka Koivisto $^{3}$, Heikki Tanila ${ }^{3}$, Tobias Hartmann ${ }^{2,4}$ (D) and Marcus O. W. Grimm ${ }^{2,4,5, *(D)}$ \\ 1 Biosciences Zoology/Physiology-Neurobiology, Faculty NT-Natural Science and Technology, Saarland \\ University, 66123 Saarbrücken, Germany; janine.mett@uni-saarland.de \\ 2 Experimental Neurology, Saarland University, 66424 Homburg, Germany; anna.lauer@uks.eu (A.A.L.); \\ daniel.janitschke@uks.eu (D.J.); lea@ifuws.de (L.V.G.); elena.theiss@web.de (E.L.T.); \\ heike.grimm@gmx.de (H.S.G.); tobias.hartmann@uks.eu (T.H.) \\ 3 A.I. Virtanen Institute, University of Eastern Finland, 70211 Kuopio, Finland; henna.koivisto@uef.fi (H.K.); \\ heikki.tanila@uef.fi (H.T.) \\ 4 Deutsches Institut für Demenzprävention, Saarland University, 66424 Homburg, Germany \\ 5 Nutrition Therapy and Counseling, Campus Rheinland, SRH University of Applied Health Sciences, \\ 51377 Leverkusen, Germany \\ * Correspondence: marcus.grimm@mx.uni-saarland.de
}

\section{check for} updates

Citation: Mett, J.; Lauer, A.A.; Janitschke, D.; Griebsch, L.V.; Theiss, E.L.; Grimm, H.S.; Koivisto, H.; Tanila, H.; Hartmann, T.; Grimm, M.O.W. Medium-Chain Length Fatty Acids Enhance A $\beta$ Degradation by Affecting Insulin-Degrading Enzyme. Cells 2021, 10, 2941. https://doi.org/ 10.3390/cells10112941

Academic Editor: Irene CozarCastellano

Received: 24 June 2021

Accepted: 26 October 2021

Published: 29 October 2021

Publisher's Note: MDPI stays neutral with regard to jurisdictional claims in published maps and institutional affiliations.

Copyright: (c) 2021 by the authors. Licensee MDPI, Basel, Switzerland. This article is an open access article distributed under the terms and conditions of the Creative Commons Attribution (CC BY) license (https:// creativecommons.org/licenses/by/ $4.0 /)$.

\begin{abstract}
The accumulation of amyloid $\beta$-protein $(\mathrm{A} \beta)$ is one of the major pathological hallmarks of Alzheimer's disease. Insulin-degrading enzyme (IDE), a zinc-metalloprotease, is a key enzyme involved in $\mathrm{A} \beta$ degradation, which, in addition to $\mathrm{A} \beta$ production, is critical for $\mathrm{A} \beta$ homeostasis. Here, we demonstrate that saturated medium-chain fatty acids (MCFAs) increase total A $\beta$ degradation whereas longer saturated fatty acids result in an inhibition of its degradation, an effect which could not be detected in IDE knock-down cells. Further analysis of the underlying molecular mechanism revealed that MCFAs result in an increased exosomal IDE secretion, leading to an elevated extracellular and a decreased intracellular IDE level whereas gene expression of IDE was unaffected in dependence of the chain length. Additionally, MCFAs directly elevated the enzyme activity of recombinant IDE, while longer-chain length fatty acids resulted in an inhibited IDE activity. The effect of MCFAs on IDE activity could be confirmed in mice fed with a MCFA-enriched diet, revealing an increased IDE activity in serum. Our data underline that not only polyunsaturated fatty acids such as docosahexaenoic acid (DHA), but also short-chain fatty acids, highly enriched, for example in coconut oil, might be beneficial in preventing or treating Alzheimer's disease.
\end{abstract}

Keywords: A $\beta$ degradation; insulin-degrading enzyme; Alzheimer's disease; fatty acids; mediumchain fatty acids; lauric acid; myristic acid; coconut oil

\section{Introduction}

One of the characteristic hallmarks of Alzheimer's disease (AD) is the progressive deposition of extracellular amyloid plaques in brain regions responsible for memory and cognition such as the hippocampus and cortex. The major component of amyloid plaques is the hydrophobic peptide amyloid- $\beta(\mathrm{A} \beta)$, which is derived from the amyloid precursor protein (APP) by the successive action of $\beta$ - and $\gamma$-secretase [1-3]. Due to multiple-site cleavages within APP, $A \beta$ peptides can vary in length, with $A \beta 38, A \beta 40$ and $A \beta 42$ (indicating 38 to 42 amino acids) representing the most abundant $A \beta$ species [2,4]. Besides $A \beta$ production, $A \beta$ elimination, involving the enzymatic degradation and the transport of the peptide, is a potent determinant of cerebral $A \beta$ levels and amyloid pathology $[5,6]$.

Several in vitro and cell-based studies demonstrated that insulin-degrading enzyme (IDE) (EC 3.4.24.56), a zinc-requiring metalloprotease, efficiently degrades $\mathrm{A} \beta$ peptides [7-10]. Besides A $\beta$, IDE cleaves several other short polypeptides including insulin, 
glucagon and amylin and, thus, additionally contributes to the regulation of the carbohydrate metabolism $[11,12]$. IDE also represents one of the major $A \beta$-degrading enzymes in vivo. IDE-deficient mice show increased cerebral $A \beta$ levels along with hyperinsulinemia and glucose intolerance, while amyloid plaque formation is decreased in the brain tissue of IDE-overexpressing animals [13-15]. Several studies highlighted a strong association among IDE level/-activity, $\mathrm{A} \beta$ accumulation and cognitive impairment in humans as well $[9,16-18]$. In line with this, some indications for a genetic association between human IDE-haplotypes and AD have been found [19-22].

Despite its predominant presence in the cytosol, IDE is localized in some organelles (endosomes, peroxisomes, mitochondria), the plasma membrane and the culture medium of microglial and neuronal cell lines [10-12,23,24]. The enzyme seems to be released via an unconventional pathway in association with exosomes [25-27] and has been detected in human serum and cerebrospinal fluid $[10,28]$. While IDE-dependent $A \beta$ degradation mainly takes place extracellularly, insulin is degraded intracellularly by the enzyme after its receptor-mediated internalization [11,12]. Several cellular signals and molecules participate in the regulation of IDE gene expression and activity. These include, among others, insulin, glucagon, cellular stress signals, adenosine triphosphate (ATP) and the APP intracellular domain (AICD) [11,29]. In a pioneering work of Hamel et al., modulatory effects of several common free fatty acids (FAs) and their acyl-coenzyme A thioesters on IDE-dependent insulin degradation were described as well. This might be based on a direct interaction between FAs and a putative "cytosolic fatty-acid binding proteins signature" within the protein [30]. In line with this, we found polyunsaturated fatty acids (PUFAs) to strongly affect the enzyme, resulting in enhanced enzymatic $A \beta$ degradation [31,32]. The latter might contribute to the beneficial effects of dietary w3-PUFAs in preventing AD or slowing down its progression $[33,34]$.

In general, lipids seem to play an important role in the pathogenesis of AD. There are extensive alterations in the lipid and fatty acid (FA) composition of human brain tissue affected by the disease. This might influence $A \beta$ production, since a strong effect of the lipid environment on proteolytic APP-processing is well established [33,34]. In contrast, the impact of lipid homeostasis on $\mathrm{A} \beta$-degrading mechanisms is largely unknown. Therefore, in the present study, we analyzed the effect of FA acyl chain length on $A \beta$ degradation. This is of particular interest as medium-chain FAs (MCFAs), similarly to PUFAs, have been reported to be advantageous in mild cognitive impairment (MCI) and early stages of AD. MCFAs are saturated FAs (SFAs) consisting of 6 to 12 carbon atoms, which can be nutritionally administered as medium-chain triglycerides (MCTs) or coconut oil. The effects of MCFAs in helping ameliorate the cognitive decline caused by AD are generally attributed to the elevation of circulating ketone bodies, compensating for the impaired cerebral glucose metabolism [35-43]. However, we recently found that the MCFA decanoic acid (10:0) promotes neuronal health independent of ketone levels by reducing oxidative stress levels [44]. The results of the present study revealed that MCFAs might additionally act by stimulating IDE-dependent $A \beta$ degradation, while saturated very long-chain FAs (VLCFAs) have the opposite effect.

\section{Materials and Methods}

\subsection{Chemicals and Reagents}

All chemicals and reagents were obtained from Merck/Sigma-Aldrich if not stated otherwise.

The following phospholipids were purchased from Avanti Polar Lipids (Alabaster, AL, USA): PC10:0/10:0 (1,2-didecanoyl-sn-glycero-3-phosphocholine), PC12:0/12:0 (1,2dilauroyl-sn-glycero-3-phosphocholine), PC14:0/14:0 (1,2-dimyristoyl-sn-glycero-3-phosphocholine), PC16:0/16:0 (1,2-dipalmitoyl-sn-glycero-3-phosphocholine), PC18:0/18:0 (1,2distearoyl-sn-glycero-3-phosphocholine), PC20:0/20:0 (1,2-diarachidoyl-sn-glycero-3-phosphocholine), PC22:0/22:0 (1,2-dibehenoyl-sn-glycero-3-phosphocholine) and PC24:0/24:0 
(1,2-dilignoceroyl-sn-glycero-3-phosphocholine). These are referred to as PC10:0, PC12:0, PC14:0, etc., in the following.

Due to the limited solubility of phosphatidylcholine (PC) species containing VLCFAs, all used phospholipids were uniformly dissolved in pre-warmed $\left(37^{\circ} \mathrm{C}\right)$ ethanol $(\mathrm{EtOH})$ to a final concentration of $2 \mathrm{mM}$ by vortexing and were stored long-term in liquid nitrogen in glass bottles.

\subsection{Cell Culture}

Mock-transfected control mouse neuroblastoma Neuro2a cells (Neuro2a control) and stable IDE knock-down cells (Neuro2a IDE KD) [31,45] were cultivated in Dulbecco's modified Eagle's medium (DMEM high glucose) containing 10\% fetal calf serum (FCS), $0.1 \mathrm{mM}$ non-essential amino acid solution (MEM), penicillin/streptomycin $(100 \mathrm{U} / \mathrm{mL}$ and $0.1 \mathrm{mg} / \mathrm{mL}$ ), $2 \mathrm{mM}$ L-glutamine, $1 \mathrm{mM}$ sodium pyruvate and $400 \mu \mathrm{g} / \mathrm{mL}$ hygromycin $\mathrm{B}$. Cells were passed by detachment with trypsin/EDTA. Cells were checked for mycoplasma before the cell lines were transferred to the laboratory and after the performance of the experiments utilizing the PCR Mycoplasma Test Kit I/C (PromoKine, Heidelberg, Germany).

To reduce the lipid content of the cell culture medium and cell proliferation, incubation of cells with phospholipids was performed in cell culture medium with reduced FCS content (DMEM/0.1\% FCS) as described earlier [31,44]. Cells used for the propidium iodide assay were treated with DMEM/0.1\% FCS containing no phenolred. Cells were grown until confluency and kept in DMEM/0.1\% FCS for $6 \mathrm{~h}$ prior to incubation. Prewarmed $\left(37^{\circ} \mathrm{C}\right) \mathrm{DMEM} / 0.1 \%$ FCS was supplemented with phospholipids in glass vials under continuous vortexing. Then, cells were treated with DMEM/0.1\% FCS containing the phospholipids in a final concentration of $10 \mu \mathrm{M}$ for $18 \mathrm{~h}$. Final EtOH concentration in the incubation medium was $5 \%$. In line with previous data [46], the cellular uptake measurement revealed an efficient uptake of all supplemented phospholipids, resulting in at least a threefold increase above the endogenous level (Supplementary Figure S1).

\subsection{Murine Serum Samples}

Serum samples derived from APPswe/PS1 $\mathrm{E} 9$ mice [47] whose diets were supplemented with coconut oil were provided by Heikki Tanila (Kuopio, Finland). For the feeding experiment, male, 8-week-old APPswe/PS1 $\triangle \mathrm{E} 9$-mice of C57Bl/6J background were housed in two groups. Animals were fed with a diet enriched in coconut oil or an isocaloric control diet enriched in high oleic sunflower oil over a period of 10 weeks (composition can be found in Supplementary Table S1). The environmental parameters were adjusted to a temperature at $20-22{ }^{\circ} \mathrm{C}$, humidity at 50-60\% and lights on for $12 \mathrm{~h}$ every day. Water and food were freely available throughout the study. At the end of the study the mice were deeply anesthetized with a pentobarbital/chloralhydrate cocktail (each $60 \mathrm{mg} / \mathrm{kg}$, i.p.). A blood sample $(\sim 300 \mu \mathrm{L})$ was collected from the heart and spun in a centrifuge at $3000 \times g$ for $1 \mathrm{~min}$ to obtain the serum.

\subsection{Collection of Conditioned Cell Culture Medium and Preparation of Cell Lysates}

Conditioned cell culture medium was collected and centrifuged for $5 \mathrm{~min}$ at $13,000 \times g$ and $4{ }^{\circ} \mathrm{C}$ in order to remove cell debris. Supernatant was used for further experiments. For the detection of extracellular IDE, conditioned cell culture medium was enriched by using Amicon Ultra Filters with a cutoff of $30 \mathrm{kDa}$ prior to gel electrophoresis.

After washing cells three times with ice cold phosphate buffered saline (PBS, $2.7 \mathrm{mM}$ $\mathrm{KCl}, 1.8 \mathrm{mM} \mathrm{KH}_{2} \mathrm{PO}_{4}, 137 \mathrm{mM} \mathrm{NaCl}, 10.1 \mathrm{mM} \mathrm{Na}_{2} \mathrm{HPO}_{4} \times 2 \mathrm{H}_{2} \mathrm{O}, \mathrm{pH} 7.4$ ), cells were scraped off in PBS and centrifuged at $13,000 \times g$ and $4{ }^{\circ} \mathrm{C}$. Supernatant was removed and cells were lysed in cell lysis buffer $(150 \mathrm{mM} \mathrm{NaCl}, 50 \mathrm{mM}$ Tris/ $\mathrm{HCl}$ pH 7.4, 2 mM EDTA, $0.1 \%$ NP-40, 0.1\% Triton-X 100) containing cOmplete protease inhibitor cocktail (EDTA-free) on ice for $60 \mathrm{~min}$. Samples were centrifuged again for $5 \mathrm{~min}$ at $13,000 \times g$ and $4{ }^{\circ} \mathrm{C}$ and supernatants were used for further experiments. 


\subsection{Measurement of Total A $\beta$ Degradation}

Total $A \beta$ degradation was measured as described earlier [31,45]. Briefly, confluent Neuro2a cells were pretreated with phospholipids for $18 \mathrm{~h}$ as described above. Without further washing of the cells, incubation medium (DMEM/0.1\% FCS $+10 \mu \mathrm{M}$ phospholipids) was exchanged for DMEM/0.1\% FCS $+10 \mu \mathrm{M}$ phospholipids $+0.5 \mu \mathrm{g} / \mathrm{mL}$ synthetic human A $\beta 40$ peptides (Botond Penke, Szeged, Hungary) (identical stock solution used for all experiments), which was incubated on cells for a further $6 \mathrm{~h}$. Remaining human $A \beta 40$ peptides in the cell culture supernatant were detected by utilizing the human $A \beta 40$ ELISA Kit (Thermo Fisher Scientific, Schwerte, Germany) according to the manufacturer's protocol or by Western Blot analysis using the antibody WO2 as described below. This antibody exclusively detects human $A \beta$ peptides and thus not the endogenous murine $A \beta$ produced by Neuro2a cells. The level of remaining human $A \beta 40$ in the cell culture supernatant is shown in figures if not stated otherwise. Linearity of $A \beta 40$ detection using Western Blot was verified by blotting human $A \beta 40$ in a concentration range of $0.5 \mu \mathrm{g} / \mathrm{mL}$ to $0 \mu \mathrm{g} / \mathrm{mL}(0.5,0.25,0.125,0.05,0.025$ and $0 \mu \mathrm{g} / \mathrm{mL})$ and quantifying the band intensities.

\subsection{Determination of Cell Viability}

Viability of Neuro2a cells after incubation with phospholipids was determined by measuring both the lactate dehydrogenase (LDH) activity in the cell culture supernatant and the staining of dead cells with propidium iodide.

LDH is a cytoplasmic enzyme which is rapidly released into the extracellular compartment when the plasma membrane is damaged [48]. LDH activity in the cell culture medium of cells treated with phospholipids was determined by using the Cytotoxicity Detection KitPLUS (Roche Diagnostics, Mannheim, Germany) according to manufacturer's instructions. A standard curve was prepared by using the cell culture supernatant of comparably confluent cells permeabilized with Triton X-100 (1\%). Resulting absorbance was measured at a wavelength of $491 \mathrm{~nm}$ in a Safire ${ }^{2}$ Fluorometer (Tecan, Crailsheim, Germany).

Propidium iodide is a small fluorescent molecule that binds to DNA but cannot passively traverse into cells that possess an intact plasma membrane [49]. To assess cell viability by using propidium iodide, cells were incubated with phospholipids in DMEM no phenolred $/ 0.1 \%$ FCS as described above. Afterwards, propidium iodide $(10 \mu \mathrm{M})$ was added to the incubation medium and incubated with cells for $10 \mathrm{~min}$ at $37^{\circ} \mathrm{C}$. Resulting fluorescence was measured at an excitation wavelength of $510 \pm 20 \mathrm{~nm}$ and an emission wavelength of $617 \pm 20 \mathrm{~nm}$ in a Safire ${ }^{2}$ Fluorometer. To measure the total cell number in each well, cells were lysed by adding Triton X-100 in a final concentration of $0.5 \%$ before fluorescence measurement was repeated.

\subsection{Quantitative Real-Time PCR}

Cells were seeded on 6-well plates and treated with phospholipids as described above. Total RNA was extracted from cells by using Trizol Reagent (Thermo Fisher Scientific, Schwerte, Germany) according to manufacturer's guidelines. The purity and concentration of the isolated RNA were analyzed by absorbance measuring using a Nano Drop 2000 (Thermo Fisher Scientific, Schwerte, Germany). Only samples with a $260 \mathrm{~nm} / 280 \mathrm{~nm}$ and a $260 \mathrm{~nm} / 230 \mathrm{~nm}$ ratio $\geq 1.8$ were used. Reverse transcription of $2 \mu \mathrm{g}$ RNA was carried out by utilizing the High-Capacity cDNA Reverse Transcription Kit (Thermo Fisher Scientific, Schwerte, Germany) according to manufacturer's protocol. Quantitative realtime PCR (RT-PCR) was performed with the Fast SYBR Green Master Mix (Thermo Fisher Scientific, Schwerte, Germany) and a PikoReal Real-Time PCR System (Thermo Fisher Scientific, Schwerte, Germany). Changes in IDE gene expression (IDE) were calculated with the $2-(\Delta \Delta \mathrm{Ct})$ method [50] after normalization to $\beta$-actin gene expression (ACTB). The following primer pairs (Eurofins MWG Operon, Eberberg, Germany) were used: ACTB: $5^{\prime}$-CCTAGGCACCAGGGTGTGAT- ${ }^{\prime}$ and $5^{\prime}$-TCTCCATGTCGTCCCAGTTG-3'; IDE: $5^{\prime}$ -

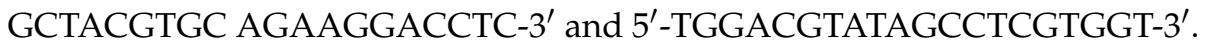




\subsection{Measurement of Total Protein Content}

Total protein concentration in samples was determined by using bicinchoninic acid (BCA) and $\mathrm{CuSO}_{4}$ according to Smith et al., [51]. Briefly, $20 \mu \mathrm{l}$ of bovine serum albumin (BSA) in a concentration range of $0.1-1.2 \mu \mathrm{g} / \mu \mathrm{L}$ were used for the generation of a standard curve. For measuring samples' protein content, 1-2 $\mu \mathrm{L}$ of each sample was pipetted in triplicate onto a 96-well plate. $200 \mu \mathrm{L}$ of reagent buffer $\left(\mathrm{CuSO}_{4}\right.$ : bicinchoninic acid; 1:39) was added to each well. After incubation for $15 \mathrm{~min}$ at $37^{\circ} \mathrm{C}$ and further $15 \mathrm{~min}$ at room temperature while shaking, absorbance was measured at a wavelength of $560 \mathrm{~nm}$ in a Safire $^{2}$ Fluorometer.

\subsection{Western Blot Analysis}

For Western Blot analysis of IDE and $\beta$-actin protein levels, samples were prepared as described above, adjusted to equal protein amounts and loaded on 10-20\% tris-tricinegradient gels (Anamed Elektrophorese, Groß-Bieberau/Rodau, Germany). For measuring total $A \beta$ degradation, the cell culture supernatant containing remaining human $A \beta 40$ was also separated in tris-tricine-gradient gels. After transferring proteins onto nitrocellulose membranes, IDE, $\beta$-actin and human $A \beta 40$ were detected with the primary antibodies ST1120 (1:2000), A5441 (1:5000) and W02 (1 $\mu \mathrm{g} / \mathrm{mL})$, all purchased from Merck, respectively. HRP-coupled antibodies W401 (anti-rabbit, 1:5000) (Promega, Mannheim, Germany) and P0260 (anti-mouse, 1:5000) (Dako, Hamburg, Germany) were utilized as secondary antibodies. Signal detection was performed with the enhanced chemiluminescence (ECL-) method (Perkin Elmer, Rodgau-Jügesheim, Germany) and densitometrical quantification of band intensity was carried out with Image Gauge software (Version 3.45) (Fujifilm). Total proteins were detected using Ponceau S staining as described in [52] before immunodetection.

\subsection{Measurement of Constitutive Protein Secretion}

Secreted alkaline phosphatase (SEAP) is a marker for the constitutive secretory pathway secreting proteins from cells regardless of external factors or signals [53]. Accordingly, for the measurement of continuous protein secretion, Neuro2a cells were transiently transfected with the vector pVectOZ-SEAP (OZ Biosciences SAS; Marseille, France) encoding for SEAP using Lipofectamine 2000 and Opti-MEM (both Thermo Fisher Scientific, Schwerte, Germany). Incubation of transfected cells with phospholipids was started $48 \mathrm{~h}$ after transfection. Culture medium was collected after phospholipid treatment as described above and boiled at $65{ }^{\circ} \mathrm{C}$ for $10 \mathrm{~min}$. In order to measure SEAP activity in the cell culture supernatant, $100 \mu \mathrm{L}$ of each sample was pipetted onto a 96-well plate and mixed with $100 \mu \mathrm{L}$ of 1-Step PNPP solution (Thermo Fisher Scientific, Schwerte, Germany). Absorbance was measured at a wavelength of $405 \mathrm{~nm}$ using a Safire ${ }^{2}$ Fluorometer.

\subsection{Measurement of IDE Activity in the Presence of Phospholipids}

Determination of the direct effect of phospholipids on IDE enzyme activity was performed as described earlier [31]. Accordingly, $50 \mathrm{ng}$ of recombinant human IDE (R\&D Systems, Minneapolis, MN, USA) was in vitro-incubated for 15 min with $10 \mu \mathrm{M}$ phospholipids in $200 \mu \mathrm{L}$ IDE assay buffer $(100 \mathrm{mM}$ Tris- $\mathrm{HCl} \mathrm{pH} 7.5,50 \mathrm{mM} \mathrm{NaCl}, 10 \mu \mathrm{M}$ $\mathrm{ZnCl}_{2}$ ) in glass vials under continuous shaking at $37^{\circ} \mathrm{C}$. Afterwards, $50 \mu \mathrm{L}$ of the IDE/PCmixture were transferred to a black 96-well-plate and mixed with the substrate McaRPPGFSAFK(Dnp)-OH (5 $\mu \mathrm{M})$ (R\&D Systems, Minneapolis, USA). Resulting fluorescence was detected continuously at an excitation wavelength of $320 \pm 10 \mathrm{~nm}$ and an emission wavelength of $405 \pm 10 \mathrm{~nm}$ in a Safire ${ }^{2}$ Fluorometer.

To analyze if IDE in the presence of the different phospholipids reduces $A \beta 40$ directly, the experiment was replicated using human $A \beta 40(0.5 \mu \mathrm{g} / \mathrm{mL})$ instead of the fluorogenic substrate. Samples were incubated for $90 \mathrm{~min}$ in glass vials under continuous shaking at $37^{\circ} \mathrm{C}$ and, afterwards, the amount of remaining human $\mathrm{A} \beta 40$ was determined using the human A $\beta 40$ ELISA Kit (Thermo Fisher Scientific, Schwerte, Germany) according to the manufacturer's protocol. 


\subsection{Measurement of IDE Activity in Murine Serum}

IDE activity in serum samples was measured according to Liu et al., with minor modifications [28]. One $\mu \mathrm{L}$ serum was diluted in ninety-nine $\mu \mathrm{L}$ IDE-Assay buffer containing cOmplete protease inhibitor cocktail (EDTA-free), $\beta$-secretase inhibitor II $(1 \mu \mathrm{M})$ and $\gamma$-secretase inhibitor IV $(25 \mu \mathrm{M})$. Samples were pipetted onto a black 96-well plate before the substrate Mca-RPPGFSAFK(Dnp)-OH $(10 \mu \mathrm{M})$ was added. Resulting fluorescence was detected as described above. IDE activity was calculated by subtracting the unspecific substrate turnover in presence of the IDE-inhibitor N-ethylmaleimide (NEM) $(1 \mathrm{mM})$ and normalization to the protein content of each serum sample.

\subsection{Mass Spectrometry Analysis}

Measurement of phospholipid uptake by Neuro2a cells was performed by using a 4000 quadrupole linear-ion trap (QTrap) equipped with a Turbo Spray ion source (AB Sciex, Darmstadt, Germany) connected to a 1200 Agilent HPLC as published earlier [31,54].

\subsection{Statistical Analysis}

All quantified data presented here are based on an average of at least three independent experiments. The exact number of independently performed experiments is stated in the corresponding figure legend. Error bars represent standard deviation of the mean. Shapiro-Wilk test and Levene's test were used for testing normal distribution and homogeneity of variance, respectively. Statistical significance was determined by two-tailed Student's $t$-test or ANOVA in case of multiple comparisons. If data were not normally distributed or heteroscedastic, statistical significance was double validated and, in the case of non-normality, statistical significance was determined via Kruskal-Wallis one-way ANOVA followed by pairwise Wilcoxon test plus Bonferroni correction or, in the case of heteroscedasticity, via Welch-ANOVA followed by Games-Howell test. Correlation coefficients were calculated by using the Pearson method. Significance levels for $p$-values are as follows: ${ }^{*} p \leq 0.05 ;{ }^{* *} p \leq 0.01$ and ${ }^{* * *} p \leq 0.001$.

\section{Results}

\subsection{FA Acyl Chain Length Affects IDE-Dependent A $\beta$ Degradation}

To analyze the effect of FA carbon chain length on total $A \beta$ degradation, mouse Neuro2a cells (Neuro2a control) were treated with SFAs of increasing length with PC as a constant headgroup (PC10:0, PC12:0, PC14:0, PC16:0, PC18:0, PC20:0, PC22:0 and PC24:0). After preincubation with the different PC species $(10 \mu \mathrm{M})$ for $18 \mathrm{~h}$, cells were incubated with the phospholipids along with synthetic human $A \beta 40$ peptides $(0.5 \mu \mathrm{g} / \mathrm{mL})$ for a further $6 \mathrm{~h}$. Afterwards, the remaining, non-degraded human $A \beta 40$ in the cell culture supernatant was quantified by western blot analysis. As shown in Supplementary Figure S2A, there was an $80.5 \pm 1.0 \%$ reduction in synthetic human $\mathrm{A} \beta 40$ concentrations corresponding to $19.5 \pm 1.0 \%$ remaining human $\mathrm{A} \beta 40$ after the $6 \mathrm{~h}$ incubation period. Considering the linear correlation $\left(R^{2}=0.9952, p<0.001\right)$ between the quantified band intensities and synthetic human $A \beta 40$ in the range of $0.5-0 \mu \mathrm{g} / \mathrm{mL}$ (Supplementary Figure S2B), one can assume that the obtained signals are within the linear range of detection.

The level of remaining human $A \beta 40$ in the medium of cells treated with the single PC species were normalized to that in the supernatant of cells treated with the control lipid PC16:0 (set at 100\%). PC16:0 contains palmitic acid (16:0), one of the most abundant SFAs within the human brain [55]. Importantly, the control lipid revealed no significant effect on total $\mathrm{A} \beta$ degradation compared to the solvent $\mathrm{EtOH}(p=0.552)$ (Supplementary Figure S3A). As illustrated in Figure 1A and Supplementary Figure S3B, a strong effect of FA acyl chain length on total $A \beta$ degradation was observed. In comparison to PC16:0, PC10:0 and PC14:0 significantly reduced the level of remaining non-degraded human A $\beta 40$ in the cell culture supernatant ( $p=0.030$ and $p=0.005$, respectively), indicating that PC10:0 and PC14:0 increase A $\beta$ degradation. Remaining human $A \beta 40$ tended to be decreased in the presence of PC12:0 as well $(p=0.092)$. In contrast, the level of remaining human 
A $\beta 40$ was slightly increased by PC20:0 and significantly elevated by PC22:0 and PC24:0 $\left(p=3.3 \times 10^{-8}\right.$ and $p=1.9 \times 10^{-4}$, respectively), again, compared to PC16:0 (Figure 1A). Based on these data, a significant correlation between the FA acyl chain length and the level of remaining human $A \beta 40$ peptides was found $\left(R^{2}=0.76, p=0.005\right)$ (Figure 1B), and the percentage reduction of the supplemented $A \beta 40$ peptides as a function of treatment was additionally calculated (Supplementary Figure S3C).

A

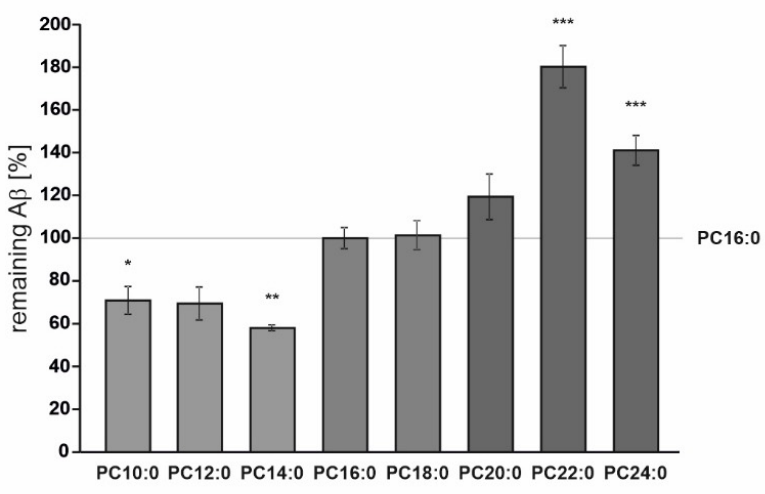

B

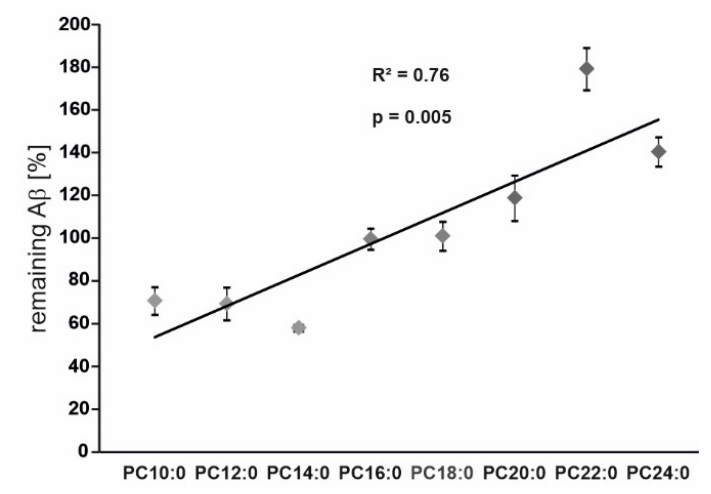

C

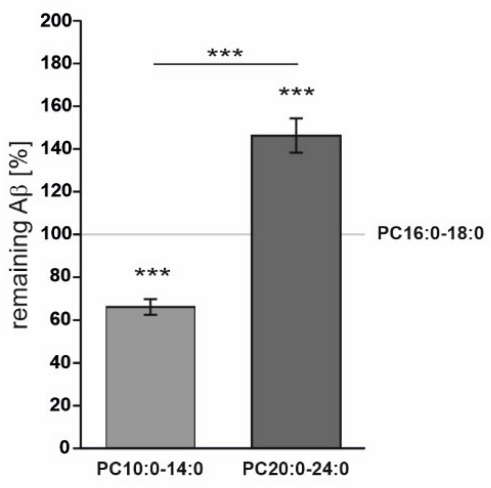

D

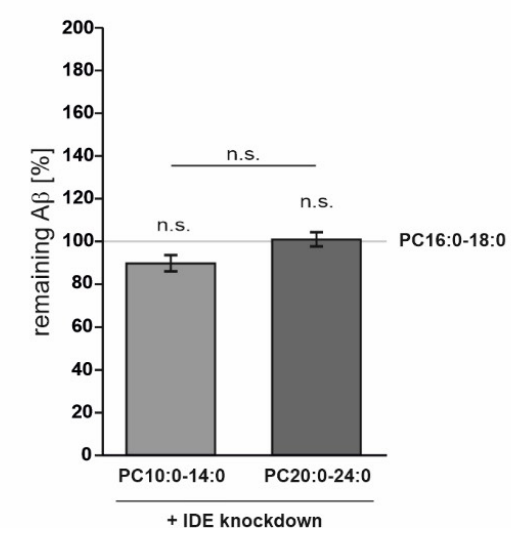

Figure 1. Effect of FA acyl chain length on IDE-dependent $A \beta$ degradation. (A) Analysis of the effect of increasing FA carbon chain length (PC10:0, PC12:0, PC14:0, PC18:0, PC20:0, PC22:0 and PC24:0) on total A $\beta$ degradation in mouse Neuro2a control cells compared to PC16:0 (set at 100\%) ( $n \geq 3$ ). (B) Pearson correlation between the FA acyl chain length and the level of remaining human $A \beta 40$ peptides $\left(R^{2}=0.76\right.$ and $\left.R=0.87\right)$. (C) Pooled analysis of the effect of the examined phospholipids on A $\beta$ degradation (PC10:0-14:0 and PC20:0-24:0 compared to PC16:0-18:0 (set at 100\%), respectively) by Western Blot $(n>11)$. (D) Investigation of the effects of FA acyl chain length on total A $\beta$ degradation in stably transfected Neuro2a IDE-knockdown cells (Neuro2a IDE KD) $(n \geq 9)$ ). Statistical significance was set as ${ }^{*} p \leq 0.05 ; * * \leq 0.01$ and ${ }^{* * *} p \leq 0.001$. n.s.: not significant.

Since PC10:0/PC12:0/PC14:0, PC16:0/PC18:0 and PC20:0/PC22:0/24:0 had similar effects on total $A \beta$ degradation (Figure 1A, Supplementary Figure S3B), phospholipids were pooled into three groups throughout the study: PC16:0-18:0 containing palmitic acid (16:0) and stearic acid (18:0) as the major SFAs in human brain tissue [55] (control, set as 100\%), PC10:0-14:0 containing MCFAs/shorter-chained FAs and PC20:0-24:0 containing VLCFAs. Evaluation of the grouped data revealed a significant reduction of remaining human $\mathrm{A} \beta 40$ to $66.8 \pm 3.7 \%$ in cells treated with PC10:0-14:0 compared to PC16:0-18:0 $\left(p=6.9 \times 10^{-6}\right)$. In contrast, PC20:0-24:0 significantly increased the level of remaining human $\mathrm{A} \beta 40$ peptides to $147.7 \pm 8.1 \%$ in comparison to PC16:0-18:0 $\left(p=1.46 \times 10^{-4}\right)$; hence, the comparison of PC10:0-14:0 to PC20:0-24:0 also revealed a significant difference 
$\left(p=1.96 \times 10^{-7}\right)$ (Figure 1C). These opposite effects on A $\beta 40$ degradation were further verified using enzyme-linked immunosorbent assay (ELISA), resulting in a significant difference in remaining A $\beta 40$ peptides in the medium of cells treated with PC10:0-14:0 $(95.3 \pm 2.6 \%)$ compared to PC20:0-24:0 $(105.3 \pm 3.4 \%)(p=0.035$; Figure S3D). These data indicate that saturated MCFAs stimulate total $\mathrm{A} \beta$ degradation, while saturated VLCFAs seem to have the opposite effect. Importantly, LDH activity in the cell culture supernatant, the cellular uptake of propidium iodide and total cell numbers were found to be unaffected by the different treatments (LDH activity: $p=0.633$; propidium iodide uptake ( - Triton): $p=0.795$; propidium iodide uptake (+Triton): $p=0.358$ ) (Supplementary Figure S3E,F). Accordingly, the observed effects are not based on alterations in membrane integrity and thus cell viability caused by the different lipids.

In order to investigate whether the effects of FA acyl chain length on total A $\beta$ degradation are dependent on IDE, the experiment was replicated by using stably transfected Neuro2a IDE-knockdown cells (Neuro2a IDE KD). IDE protein level and total A $\beta$ degradation is strongly reduced in this cell line compared to the mock-transfected control cells (Neuro2a control) used above (Supplementary Figure S4A,B) [31,45]. As shown in Figure 1D, neither PC10:0-14:0 nor PC20:0-24:0 significantly affected total A $\beta$ degradation in the Neuro2a IDE KD cells compared to PC16:0-18:0 $(p=0.129$ and $p=0.969$, respectively). In this cell line, none of the used single PC species significantly altered the total A $\beta$ degradation in comparison to PC16:0 (Supplementary Figure S4C,D). Accordingly, and in contrast to the corresponding control cells, Neuro2a IDE KD cells displayed no significant correlation between the FA acyl chain length and the level of remaining human A $\beta 40$ peptides $\left(R^{2}=0.17, p=0.31\right.$ ) (Supplementary Figure S4E). These results indicate that saturated MCFAs/shorter-chained FAs and saturated VLCFAs affect $A \beta$ degradation conducted by IDE.

\subsection{FA Acyl Chain Length Affects the Secretion of IDE and Its Catalytic Activity}

MCFAs are endogenous activators of the peroxisome proliferator activated receptor $\gamma$ (PPAR $\gamma$ ). PPAR $\gamma$ binds to a functional peroxisome proliferator-response element (PPRE) in the IDE promoter region and has been reported to promote IDE gene transcription in primary neurons $[56,57]$. For these reasons, we analyzed whether IDE gene expression is affected by FA acyl chain length under the conditions chosen in the present study. RT-PCR analysis revealed that the treatment of Neuro2a control cells with both PC10:0-14:0 and PC20:0-24:0 had no impact on IDE gene expression compared to control ( $p=0.763$ and $p=0.717$, respectively) (Figure 2A). This finding demonstrates that the FA acyl chain length-dependent effects on IDE-dependent $A \beta$ degradation (Figure 1) are not based on alterations in IDE gene expression.

As already mentioned, IDE seems to be released into the extracellular space in association with exosomes, where it plays a major role in the catabolism of secreted $\mathrm{A} \beta$ peptides $[24,25]$. To further clarify the mechanism by which FA acyl chain length affects IDE-dependent $A \beta$ degradation, we analyzed the impact of PC10:0-14:0 and PC20:0-24:0 on the cellular sorting of IDE. Western Blot analysis revealed that the cellular content of $\beta$-actin as control showed no significant difference for all treatments (PC10:0-14:0 vs. PC16:0-18:0: $p=0.716$; PC20:0-24:0 vs. PC16:0-18:0: $p=0.952$ ) (Supplementary Figure S5A). In contrast, a significantly elevated extracellular IDE protein level $(138.9 \pm 7.8 \%$, $\left.p=2.3 \times 10^{-4}\right)$, along with a significantly reduced intracellular IDE protein content (76.1 $\pm 4.4 \%, p=0.040)$, were observed in cells treated with PC10:0-14:0 compared to PC16:0-18:0 (Figure 2B). Thus, the stimulated A $\beta$ degradation in cells treated with PC10:014:0 might be due to an increased IDE release into the extracellular compartment. To exclude that this effect is caused by general alterations in protein secretion, SEAP activity was measured in the medium of treated cells transiently expressing SEAP. SEAP activity in the cell culture supernatant and hence protein secretion through the constitutive, unregulated secretory pathway was slightly (below 5\%) altered for PC20:0-24:0 vs. PC16:0-18:0 (PC10:0-14:0 vs. PC16:0-18:0: $p=0.242$; PC20:0-24:0 vs. PC16:0-18:0: $104.6 \pm 1.49 \%$, 
$p=0.045$ ) (Supplementary Figure S5B). Accordingly, PC10:0-14:0 seems to specifically stimulate the release of IDE into the extracellular space resulting in an increased clearance of the supplemented human A $\beta 40$ peptides. In contrast, PC20:0-24:0 had no effect on IDE sorting since neither the extracellular nor the intracellular IDE protein level was altered in cells incubated with PC20:0-24:0 compared to control ( $p=1.000$ and $p=0.571$, respectively) (Figure 2B). This indicates that the reduced $A \beta$ degradation in cells treated with PC20:0-24:0 should be attributed to another mechanism of action.

A

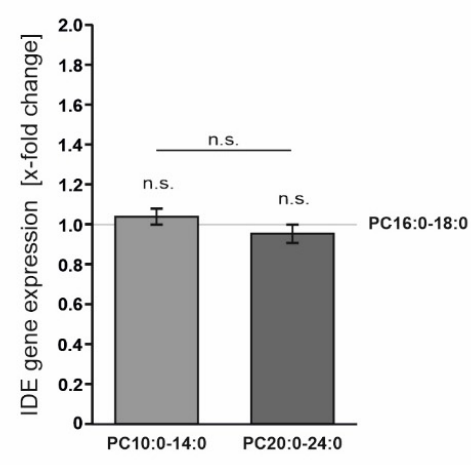

C

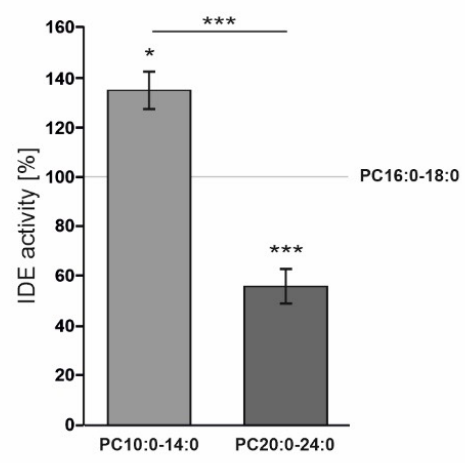

B

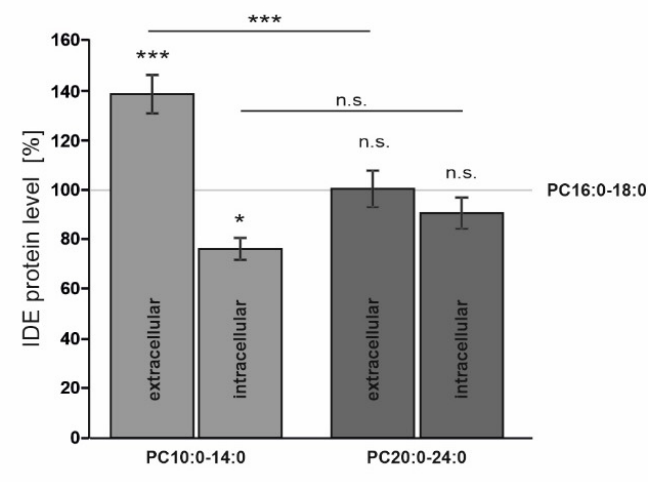

D

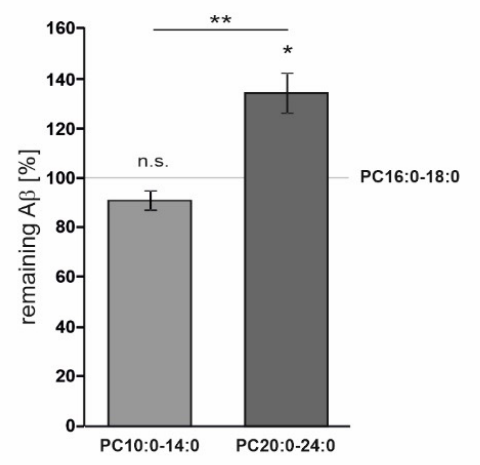

E

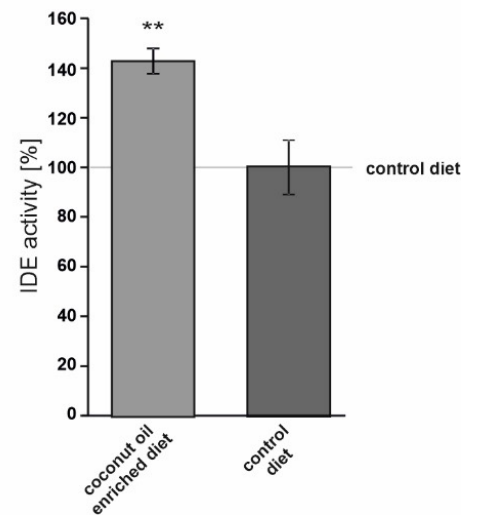

Figure 2. Effect of FA acyl chain length on IDE secretion and catalytic activity. (A) Real time PCR analysis of the effect of FA carbon chain length (PC10:0-14:0 and PC20:0-24:0 compared to PC16:0-18:0, respectively) on Ide gene expression in Neuro2a control cells $(n \geq 11)$. (B) Analysis of the impact of PC10:0-14:0 and PC20:0-24:0 on the cellular sorting of IDE in Neuro2a control cells. Extracellular and intracellular IDE protein levels were examined by Western Blot $(n \geq 9)$. $(C, D)$ Examination of the direct effect of the FA acyl chain length on the catalytic activity of IDE by using the fluorogenic substrate Mca-RPPGFSAFK(Dnp)-OH $(n \geq 12)(\mathbf{C})$ or human A $\beta 40$ peptides $(n=5)(\mathbf{D})$. (E) Effect of MCFAs on IDE activity investigated in the serum of APPswe/PS1 $\triangle \mathrm{E} 9$ mice fed with a diet enriched in coconut oil containing high amounts of MCFAs or an isocaloric control diet $(n=7)$. Statistical significance was set as ${ }^{*} p \leq 0.05,{ }^{* *} p \leq 0.01$ and ${ }^{* * *} p \leq 0.001$. n.s.: not significant.

For this reason, the direct effect of the FA acyl chain length on the catalytic activity of IDE was assessed. Recombinant human IDE was in vitro-incubated with the different PC species prior to the addition of the fluorogenic substrate Mca-RPPGFSAFK(Dnp)-OH and the subsequent measurement of the resulting fluorescence. IDE activity was significantly increased to $134.9 \pm 7.6 \%$ in the presence of PC10:0-14:0 in comparison to PC16:0-18:0 $(p=0.0133)$ and significantly reduced in the presence of PC20:0-24:0 $(56.0 \pm 6.9 \%$, $p=0.0015)$. Thus, the comparison of PC10:0-14:0 to PC20:0-24:0 showed a significant difference as well $(p<0.001)$ (Figure $2 \mathrm{C})$. The experiment was replicated utilizing synthetic human $A \beta 40$ instead of the fluorogenic substrate, leading to similar results. ELISA measurement showed PC10:0-14:0 to slightly reduce the remaining human A $\beta 40$ peptides 
compared to PC16:0-18:0 (89.6 $\pm 4.1 \%)$. However, this effect did not reach significance $(p=0.537)$. In contrast, PC20:0-24:0 significantly increased the non-degraded human A $\beta 40$ compared to both PC16:0-18:0 (133.2 $\pm 8.2 \%, p=0.011)$ and PC10:0-14:0 $(p=0.002)$ (Figure 2D). Thus, the catalytic activity of IDE seems to be directly stimulated by saturated MCFAs/shorter-chained FAs, while it is inhibited by saturated VLCFAs.

To examine whether MCFAs also affect IDE in live animals, APPswe/PS1 $\mathrm{E} 9$ mice were fed with a diet enriched with coconut oil, containing high amounts of MCFAs, or an isocaloric control diet for 10 weeks. Afterwards, IDE activity was measured in serum samples, representing the extracellular environment. As already mentioned, IDE has been detected in human serum and cerebrospinal fluid $[10,28]$. It is one of the major proteases involved in the cleavage of the fluorogenic substrate Mca-RPPGFSAFK (Dnp)$\mathrm{OH}$ in human serum reflecting the degradation of $\mathrm{A} \beta$ [28]. Since this substrate is not specific to any particular protease, IDE activity was calculated by subtracting the unspecific background of the substrate turnover determined in the presence of the IDE-inhibitor NEM. As illustrated in Figure 2E, the catalytic activity of IDE was significantly increased to $142.4 \pm 5.0 \%$ in the serum of mice fed with the coconut oil-enriched diet compared to control chow $\left(p=4.32 \times 10^{-3}\right)$. These data show that the supplementation of saturated MCFAs also increases the activity of IDE in the extracellular compartment in an ex vivo model.

\section{Discussion}

The relationship between $A \beta$ generation and degradation determines the cerebral $A \beta$ accumulation, which is one of the major histopathological hallmarks of AD $[5,6]$. While it is well established that $A \beta$ production is strongly affected by lipids and FAs [33,34], less is known about the impact of the lipid environment on $A \beta$ degradation. Therefore, in the present study, we analyzed the effect of FA acyl chain length on the enzymatic degradation of the peptide.

Neuro2a cells were exposed to saturated FAs with an acyl chain length ranging from 10 to $24 \mathrm{C}$-atoms before total $\mathrm{A} \beta$ degradation was measured. PC represents the most abundant phospholipid in mammalian cellular membranes [58], palmitic acid (16:0) and stearic acid (18:0) are the major SFAs in human brain tissue [55]. Correspondingly, FAs were applied as PCs containing identical FAs in the sn1- and sn2-position, and PC16:0 or PC16:0-18:0 (for the grouped evaluation) were chosen as controls. This experimental setup enabled us to analyze the impact of the FA acyl chain length regardless of possible effects of the choline headgroup or the glycerophosphoric acid. Liposomes containing the used phospholipids are efficiently taken up by cells. This results in the incorporation of the supplemented PCs into cellular membranes, probably affecting, e.g., membrane fluidity and structure, or their phospholipase A-dependent hydrolysis into lysolipids and free FAs [59].

In Neuro2a cells, PCs containing MCFAs and shorter-chained FAs (PC10:0-14:0) significantly stimulated the degradation of exogenous human $A \beta 40$ peptides conducted by IDE, one of the major $A \beta$-degrading proteases $[10,13,15]$. The elevated $A \beta$ degradation in the presence of PC10:0-14:0 was accompanied by changes in IDE sorting and a direct stimulating effect on IDE activity (Figure 3). PC10:0-14:0 was found to specifically increase the release of IDE into the extracellular space, a process which occurs at least partially in association with exosomes [25,26]. IDE exosomally released by Neuro2a has been reported to be proteolytically active as the inhibition of exosome release leads to increased endogenous $A \beta$ levels in the cell culture supernatant [25]. Considering that both exosome release in general and exosome-associated IDE secretion are known to be strongly affected by various lipids [26,31,60-63], one can assume that saturated MCFAs and shorter-chained FAs stimulate the exosomal IDE secretion into the extracellular compartment. This might lead to the elevated degradation of synthetic human $\mathrm{A} \beta 40$ peptides added to the medium of cells treated with PC10:0-14:0, which could be further strengthened by the increased IDE activity in presence of these PC species. In this context, a recent publication of Song et al. should be mentioned which reports that IDE is not secreted from cultured cells, 
but rather released nonspecifically as a consequence of reduced membrane integrity. In this study, only $\sim 1 \%$ of total cellular IDE was released from HEK-293 and BV-2 cells. In the conditioned medium of intact Neuro2a cells, the enzyme was almost undetectable, even after concentrating the samples 10-fold [64]. In contrast, we and others [25] found measurable amounts of IDE in the cell culture supernatant of this cell line. Possible reasons for these divergent results include differences in the used growth medium, the cell to medium ratios, the methods for the concentration and detection of IDE as well as clonal heterogeneity. Further, Song et al. found LDH and two other measured cytosolic markers (glyceraldehyde dehydrogenase (GAPDH) and pitrilysin) to be released at the same relative levels as IDE from HEK-293 and BV-2 cells treated with lovastatin, implying that IDE is released nonspecifically by lysed cells [64]. However, unlike lovastatin, PC10:0-14:0 seems to specifically stimulate the secretion of IDE since it did not affect the release of SEAP, a marker for the constitutive secretory pathway [53]. Additionally, two established indicators for cytolysis, the activity of LDH in the conditioned cell culture medium and the cellular uptake of PI $[48,49]$, were unaltered by the different phospholipids. Altogether, these data make a disruption of plasma membrane integrity very unlikely as the cause for the increased IDE release from cells treated with PC10:0-14:0. This is in line with other studies reporting a release of IDE into the cell culture supernatant in the absence of detectable $\mathrm{LDH}[10,25]$. The reason for these differences is unclear but could be based on differences in the cell lines used and the cytotoxic potential of the applied stimulants.

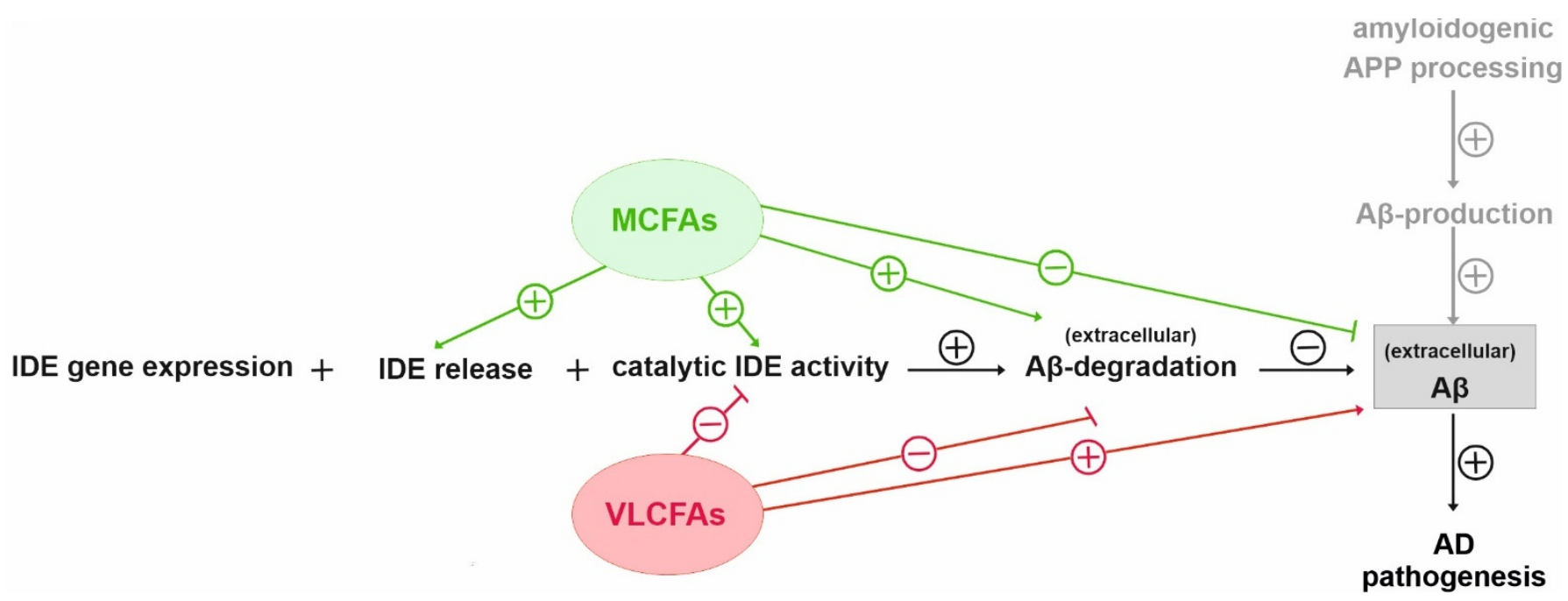

Figure 3. Schematic overview of the proposed effects of MCFAs and VLCFAs on IDE dependent A $\beta$ degradation. The increased $\mathrm{A} \beta$ degradation in the presence of PC10:0-14:0 seemed to be based on changes in IDE sorting and a direct stimulating effect on IDE activity. In contrast, PC20:0-24:0 decreased the IDE-dependent A $\beta$ degradation, probably by directly inhibiting the catalytic activity of the enzyme.

On the other hand, the saturated VLFAs contained in PC20:0-24:0 significantly reduced the IDE-dependent $A \beta$ degradation, probably by directly inhibiting the catalytic activity of the enzyme (Figure 3). In line with these data, an in vitro-inhibition of IDE-dependent insulin degradation by long-chain free FAs (C16-C20) with IC50-values ranging from 10 to $50 \mu \mathrm{M}$ has been reported in the study by Hamel et al., mentioned above [30]. A direct interaction between FAs and IDE is further supported by the suspected "cytosolic fattyacid binding proteins signature" within the enzyme and our previous observation that different FAs distinctly bind to recombinant IDE [30,31]. Altogether, our cell culture data indicate that saturated MCFAs and shorter-chained FAs are more beneficial than saturated longer-chained FAs and VLCFAs with respect to IDE-dependent A $\beta$ degradation.

An increased IDE activity was also observed in the serum of mice upon dietary supplementation of MCFAs in the form of coconut oil. We would like to point out that the effects obtained with transgenic mice fed with coconut oil are comparable to the effects 
observed in cell culture. By utilizing an IDE knock-down, we could confirm that the major effect of coconut oil is linked to the A $\beta$ degrading enzyme IDE. Due to limitation of samples size in mice, this confirmation which would be ideally done by a specific inhibitor of IDE (e.g., $6 \mathrm{bK}$ ) was not possible. Therefore, we cannot rule out that, in vivo, other proteases besides IDE are affected by coconut oil, which is a potential caveat in our study. In addition, we suggest further studies investigating whether mutations in the "cytosolic fatty acid binding protein signature" would reinforce the notion that MCFAs regulate IDE. In order to address this question, further research is warranted.

IDE activity in murine serum samples was determined by using the fluorogenic substrate Mca-RPPGFSAFK (Dnp)-OH (also called substrate V) and the subsequent subtraction of its turnover in the presence of the IDE inhibitor NEM. In this context, it should be noted that both the used substrate and NEM are not specific for IDE: substrate V can be cleaved by several other metalloproteases as well and NEM acts as a general irreversible inhibitor of cysteine peptidases. However, IDE and angiotensin converting enzyme (ACE) are the major proteases in human serum to mediate substrate $\mathrm{V}$ degradation, as reported by Liu et al. Among several inhibitors tested, only insulin, amylin, EDTA and the ACE inhibitor lisinopril had the ability to inhibit substrate $\mathrm{V}$ degradation in human serum. The existence of IDE activity in these samples was further confirmed by immunocapture of IDE using monoclonal antibodies. Importantly, in the same study, substrate $V$ turnover in serum was strongly inhibited by increasing doses of $A \beta$ and thus seems to reflect $A \beta$ degradation [28]. Altogether, these data indicate that IDE is one of the major serum proteases affected by MCFAs/coconut oil. Nevertheless, we cannot completely rule out the possibility that ACE activity is also altered by the coconut oil-enriched diet. Utilizing short fluorogenic peptides as substrates is discussed as having further disadvantages [65]. In particular, under certain conditions, using small fluorogenic peptides to monitor IDE activity might result in the identification of "false-positive" or "false-negative" IDE modulators. Therefore, an independent confirmation of the identified IDE activity modulators is extremely important. In this study, we confirmed our results by using an IDE knock-down cell line. Effects observed in the presence of MCFAs were attenuated or disappeared in the absence of IDE, suggesting that IDE is the major protease responsible for the MCFA-affected A $\beta$ degradation. In detail, to analyze $A \beta$ degradation with a chemically not-modified substrate, we used N2a cells. $\mathrm{N} 2 \mathrm{a}$ cells are mouse neuroblastoma cells producing $\mathrm{A} \beta$ peptides that are not or are in very low amounts detected by the antibody $\mathrm{WO} 2$, specific for human $\mathrm{A} \beta$. These mouse cell lines were incubated with human $A \beta$ peptides in the presence or absence of MCFAs. WB analysis using the $\mathrm{WO} 2$ antibody revealed that the remaining human $A \beta$ in the presence of MCFAs is decreased, further suggesting that MCFAs increase $A \beta$ degradation in an assay which is not influenced by fluorogenic substrates. Notably, this effect could be not observed in IDE knock-down N2a cells.

Considering the observed effects of MCFAs on IDE in Neuro2a cells, the increased serum IDE activity upon dietary coconut oil supplementation might be based on an enhanced IDE release into the extracellular space in combination with a direct stimulation of its catalytic activity. The increased serum IDE activity after MCFA supplementation probably leads to reduced peripheral A $\beta$ levels. According to the 'peripheral sink hypothesis,' the latter should be associated with an increased $A \beta$ efflux from brain tissue $[66,67]$. In line with this and further emphasizing the relevance of our results, Liu et al. reported a negative association between probable $\mathrm{AD}$ and $\mathrm{MCI}$ and the activity of serum proteases mediating $A \beta$ degradation measured by using the same substrate [28]. As MCFAs are able to cross the blood brain barrier [68,69], one might speculate that they could also affect the secretion and activity of IDE in the central nervous system. This would be of particular importance since extracellular IDE might play a key role in the clearance of extracellularly accumulating $A \beta$ peptides within brain tissue, which are closely linked to $A D$ pathology. It should be additionally mentioned that a trend towards decreased total $A \beta$ levels in the parietal lobe of dogs, dietarily administrated with MCTs, has been reported. However, in this study, $A \beta$ degradation was not analyzed and the tendentially reduced cerebral $A \beta$ 
levels after MCT-supplementation were attributed to a lessened APP protein level [70]. Beside $A \beta$ degradation mediated by IDE, hepatic clearance of $A \beta$ peptide might also be an important factor and may be influenced by coconut oil, which should be addressed in further studies. In detail, on the one hand insulin can be considered as a potential competitive inhibitor for $A \beta$ degradation as it is another substrate for IDE [71]. Therefore, reduction in insulin might result in an increased $A \beta$ degradation by IDE. On the other hand, insulin affects LRP mediated hepatic clearance of $A \beta$ [72], further underlying the complexicity of $A \beta$ catabolism.

Further studies are needed to analyze the possible link between the observed increased serum IDE activity after MCFA supplementation and cerebral $A \beta$ levels as well as the mechanism by which MCFAs might affect IDE in vivo.

In summary, the data of the present study further underline the protective properties of saturated MCFAs in respect to AD pathogenesis. Our results indicate that the beneficial effects of MCFAs for MCI- and AD-patients might not only be based on an elevation of circulating ketone bodies improving cerebral energy metabolism and the reduction in oxidative stress levels [35-44], but also by a stimulation of IDE-dependent $A \beta$ degradation. Interestingly, an association between variants of the polymorphisms in the IDE gene and the cognitive response of AD-patients to MCT-supplementation has been described [73], further emphasizing a connection between MCFAs and IDE in humans. Considering the various substrates of IDE, an MCFA-induced elevation of IDE-activity might also affect other important pathways including those regulating carbohydrate metabolism. However, further particular clinical studies are needed to evaluate the potential of MCFAs for nutritional and pharmacological interventions regarding AD.

Supplementary Materials: The following are available online at https:/ / www.mdpi.com/article/ 10.3390/cells10112941/s1. Figure S1: Phospholipid uptake by Neuro2a cells, Figure S2: Western Blot analysis of total A $\beta$ degradation, Figure S3: Effect of FA acyl chain length on cell viability and A $\beta$ degradation in Neuro2a cells, Figure S4: Effect of FA acyl chain length on A $\beta$ degradation in stably transfected Neuro2a IDE-knockdown cells (Neuro2a IDE KD), Figure S5: Effect of FA acyl chain length on $\beta$-actin protein level in Neuro2a cells and constitutive protein secretion, Table S1. Composition of the diet enriched in coconut oil purchased from Merck/Sigma-Aldrich.

Author Contributions: Conceptualization, M.O.W.G.; Funding acquisition, T.H.; Investigation, J.M., A.A.L., D.J., L.V.G., E.L.T., H.S.G., H.K. and H.T.; Project administration, M.O.W.G.; Writing—original draft, J.M.; Writing—review \& editing, A.A.L., D.J., H.S.G., T.H. and M.O.W.G. All authors have read and agreed to the published version of the manuscript.

Funding: Funding was supported by the European Commission under the framework programme of the European Union [grant agreement no. 211696] LipiDiDiet; EU Joint Programme-Neurodegenerative Disease Research (JPND) and BMBF grants MIND-AD (01ED1509) and EURO-FINGERS (01ED2003). We acknowledge support by the Deutsche Forschungsgemeinschaft (DFG, German Research Foundation) and Saarland University within the funding programme Open Access Publishing.

Institutional Review Board Statement: All animal experiments were conducted in accordance with the EU directive 2010/63/EU for animal well-being, using protocols approved by the Animal Experiment Board of Finland (ESAVI-2474-04.10.07-2013).

Informed Consent Statement: Not applicable.

Data Availability Statement: Not applicable.

Conflicts of Interest: The authors declare no conflict of interest.

\section{References}

1. Masters, C.L.; Selkoe, D.J. Biochemistry of amyloid beta-protein and amyloid deposits in Alzheimer disease. Cold Spring Harb. Perspect. Med. 2012, 2, a006262. [CrossRef] [PubMed]

2. Chen, G.F.; Xu, T.H.; Yan, Y.; Zhou, Y.R.; Jiang, Y.; Melcher, K.; Xu, H.E. Amyloid beta: Structure, biology and structure-based therapeutic development. Acta Pharmacol. Sin. 2017, 38, 1205-1235. [CrossRef] 
3. De Strooper, B. Proteases and proteolysis in Alzheimer disease: A multifactorial view on the disease process. Physiol. Rev. 2010, 90, 465-494. [CrossRef]

4. Grimm, M.O.; Mett, J.; Stahlmann, C.P.; Haupenthal, V.J.; Zimmer, V.C.; Hartmann, T. Neprilysin and Abeta Clearance: Impact of the APP Intracellular Domain in NEP Regulation and Implications in Alzheimer's Disease. Front. Aging Neurosci. $2013,5,98$. [CrossRef]

5. Nalivaeva, N.N.; Turner, A.J. Targeting amyloid clearance in Alzheimer's disease as a therapeutic strategy. Br. J. Pharmacol. 2019, 176, 3447-3463. [CrossRef]

6. Saido, T.; Leissring, M.A. Proteolytic degradation of amyloid beta-protein. Cold Spring Harb. Perspect. Med. 2012, 2, a006379. [CrossRef] [PubMed]

7. Chesneau, V.; Vekrellis, K.; Rosner, M.R.; Selkoe, D.J. Purified recombinant insulin-degrading enzyme degrades amyloid beta-protein but does not promote its oligomerization. Biochem. J. 2000, 351 Pt 2, 509-516. [CrossRef]

8. Kurochkin, I.V.; Goto, S. Alzheimer's beta-amyloid peptide specifically interacts with and is degraded by insulin degrading enzyme. FEBS Lett. 1994, 345, 33-37. [CrossRef]

9. Perez, A.; Morelli, L.; Cresto, J.C.; Castano, E.M. Degradation of soluble amyloid beta-peptides 1-40, 1-42, and the Dutch variant 1-40Q by insulin degrading enzyme from Alzheimer disease and control brains. Neurochem. Res. 2000, 25, 247-255. [CrossRef] [PubMed]

10. Qiu, W.Q.; Walsh, D.M.; Ye, Z.; Vekrellis, K.; Zhang, J.; Podlisny, M.B.; Rosner, M.R.; Safavi, A.; Hersh, L.B.; Selkoe, D.J. Insulindegrading enzyme regulates extracellular levels of amyloid beta-protein by degradation. J. Biol. Chem. 1998, 273, 32730-32738. [CrossRef] [PubMed]

11. Pivovarova, O.; Hohn, A.; Grune, T.; Pfeiffer, A.F.; Rudovich, N. Insulin-degrading enzyme: New therapeutic target for diabetes and Alzheimer's disease? Ann. Med. 2016, 48, 614-624. [CrossRef]

12. Tundo, G.R.; Sbardella, D.; Ciaccio, C.; Grasso, G.; Gioia, M.; Coletta, A.; Polticelli, F.; Di Pierro, D.; Milardi, D.; Van Endert, P.; et al. Multiple functions of insulin-degrading enzyme: A metabolic crosslight? Crit Rev. Biochem. Mol. Biol. 2017, 52, 554-582. [CrossRef]

13. Farris, W.; Mansourian, S.; Chang, Y.; Lindsley, L.; Eckman, E.A.; Frosch, M.P.; Eckman, C.B.; Tanzi, R.E.; Selkoe, D.J.; Guenette, $\mathrm{S}$. Insulin-degrading enzyme regulates the levels of insulin, amyloid beta-protein, and the beta-amyloid precursor protein intracellular domain in vivo. Proc. Natl. Acad. Sci. USA 2003, 100, 4162-4167. [CrossRef]

14. Leissring, M.A.; Farris, W.; Chang, A.Y.; Walsh, D.M.; Wu, X.; Sun, X.; Frosch, M.P.; Selkoe, D.J. Enhanced proteolysis of beta-amyloid in APP transgenic mice prevents plaque formation, secondary pathology, and premature death. Neuron 2003, 40, 1087-1093. [CrossRef]

15. Miller, B.C.; Eckman, E.A.; Sambamurti, K.; Dobbs, N.; Chow, K.M.; Eckman, C.B.; Hersh, L.B.; Thiele, D.L. Amyloid-beta peptide levels in brain are inversely correlated with insulysin activity levels in vivo. Proc. Natl. Acad. Sci. USA 2003, 100, 6221-6226. [CrossRef] [PubMed]

16. Cook, D.G.; Leverenz, J.B.; McMillan, P.J.; Kulstad, J.J.; Ericksen, S.; Roth, R.A.; Schellenberg, G.D.; Jin, L.W.; Kovacina, K.S.; Craft, S. Reduced hippocampal insulin-degrading enzyme in late-onset Alzheimer's disease is associated with the apolipoprotein E-epsilon4 allele. Am. J. Pathol. 2003, 162, 313-319. [CrossRef]

17. Stargardt, A.; Gillis, J.; Kamphuis, W.; Wiemhoefer, A.; Kooijman, L.; Raspe, M.; Benckhuijsen, W.; Drijfhout, J.W.; Hol, E.M.; Reits, E. Reduced amyloid-beta degradation in early Alzheimer's disease but not in the APPswePS1dE9 and 3xTg-AD mouse models. Aging Cell 2013, 12, 499-507. [CrossRef]

18. Zhao, Z.; Xiang, Z.; Haroutunian, V.; Buxbaum, J.D.; Stetka, B.; Pasinetti, G.M. Insulin degrading enzyme activity selectively decreases in the hippocampal formation of cases at high risk to develop Alzheimer's disease. Neurobiol. Aging 2007, 28, 824-830. [CrossRef]

19. Ertekin-Taner, N.; Allen, M.; Fadale, D.; Scanlin, L.; Younkin, L.; Petersen, R.C.; Graff-Radford, N.; Younkin, S.G. Genetic variants in a haplotype block spanning IDE are significantly associated with plasma Abeta42 levels and risk for Alzheimer disease. Hum. Mutat. 2004, 23, 334-342. [CrossRef]

20. Zuo, X.; Jia, J. Promoter polymorphisms which modulate insulin degrading enzyme expression may increase susceptibility to Alzheimer's disease. Brain Res. 2009, 1249, 1-8. [CrossRef] [PubMed]

21. Reitz, C.; Cheng, R.; Schupf, N.; Lee, J.H.; Mehta, P.D.; Rogaeva, E.; St George-Hyslop, P.; Mayeux, R. Association between variants in IDE-KIF11-HHEX and plasma amyloid beta levels. Neurobiol. Aging 2012, 33, 199.e13-199.e17. [CrossRef] [PubMed]

22. Wang, S.; He, F.; Wang, Y. Association between polymorphisms of the insulin-degrading enzyme gene and late-onset Alzheimer disease. J. Geriatr. Psychiatry Neurol. 2015, 28, 94-98. [CrossRef] [PubMed]

23. Qiu, W.Q.; Ye, Z.; Kholodenko, D.; Seubert, P.; Selkoe, D.J. Degradation of amyloid beta-protein by a metalloprotease secreted by microglia and other neural and non-neural cells. J. Biol. Chem. 1997, 272, 6641-6646. [CrossRef] [PubMed]

24. Vekrellis, K.; Ye, Z.; Qiu, W.Q.; Walsh, D.; Hartley, D.; Chesneau, V.; Rosner, M.R.; Selkoe, D.J. Neurons regulate extracellular levels of amyloid beta-protein via proteolysis by insulin-degrading enzyme. J. Neurosci. 2000, 20, 1657-1665. [CrossRef]

25. Bulloj, A.; Leal, M.C.; Xu, H.; Castano, E.M.; Morelli, L. Insulin-degrading enzyme sorting in exosomes: A secretory pathway for a key brain amyloid-beta degrading protease. J. Alzheimers. Dis. 2010, 19, 79-95. [CrossRef] 
26. Tamboli, I.Y.; Barth, E.; Christian, L.; Siepmann, M.; Kumar, S.; Singh, S.; Tolksdorf, K.; Heneka, M.T.; Lutjohann, D.; Wunderlich, P.; et al. Statins promote the degradation of extracellular amyloid \{beta\}-peptide by microglia via stimulation of exosome-associated insulin-degrading enzyme (IDE) secretion. J. Biol. Chem. 2010, 285, 37405-37414. [CrossRef]

27. Zhao, J.; Li, L.; Leissring, M.A. Insulin-degrading enzyme is exported via an unconventional protein secretion pathway. Mol. Neurodegener. 2009, 4, 4. [CrossRef]

28. Liu, Z.; Zhu, H.; Fang, G.G.; Walsh, K.; Mwamburi, M.; Wolozin, B.; Abdul-Hay, S.O.; Ikezu, T.; Leissring, M.A.; Qiu, W.Q. Characterization of insulin degrading enzyme and other amyloid-beta degrading proteases in human serum: A role in Alzheimer's disease? J. Alzheimers Dis. 2012, 29, 329-340. [CrossRef]

29. Lauer, A.A.; Mett, J.; Janitschke, D.; Thiel, A.; Stahlmann, C.P.; Bachmann, C.M.; Ritzmann, F.; Schrul, B.; Muller, U.C.; Stein, R.; et al. Regulatory feedback cycle of the insulin-degrading enzyme and the amyloid precursor protein intracellular domain: Implications for Alzheimer's disease. Aging Cell 2020, 19, e13264. [CrossRef]

30. Hamel, F.G.; Upward, J.L.; Bennett, R.G. In vitro inhibition of insulin-degrading enzyme by long-chain fatty acids and their coenzyme A thioesters. Endocrinology 2003, 144, 2404-2408. [CrossRef]

31. Grimm, M.O.; Mett, J.; Stahlmann, C.P.; Haupenthal, V.J.; Blumel, T.; Stotzel, H.; Grimm, H.S.; Hartmann, T. Eicosapentaenoic acid and docosahexaenoic acid increase the degradation of amyloid-beta by affecting insulin-degrading enzyme. Biochem. Cell Biol. 2016, 94, 534-542. [CrossRef] [PubMed]

32. Du, J.; Zhang, L.; Liu, S.; Wang, Z. Palmitic acid and docosahexaenoic acid opposingly regulate the expression of insulin-degrading enzyme in neurons. Pharmazie 2010, 65, 231-232.

33. Grimm, M.O.; Mett, J.; Grimm, H.S.; Hartmann, T. APP Function and Lipids: A Bidirectional Link. Front. Mol. Neurosci. 2017, 10, 63. [CrossRef]

34. Mett, J.; Hartmann, T.; Grimm, M.O.W. The Effects of Glycerophospholipids and Fatty Acids on APP Processing: Implications for Alzheimer's Disease. In Handbook of Lipids in Human Function; Elsevier: Urbana, IL, USA, 2016; pp. $377-421$.

35. Fernando, W.M.; Martins, I.J.; Goozee, K.G.; Brennan, C.S.; Jayasena, V.; Martins, R.N. The role of dietary coconut for the prevention and treatment of Alzheimer's disease: Potential mechanisms of action. Br. J. Nutr. 2015, 114, 1-14. [CrossRef]

36. Chatterjee, P.; Fernando, M.; Fernando, B.; Dias, C.B.; Shah, T.; Silva, R.; Williams, S.; Pedrini, S.; Hillebrandt, H.; Goozee, K.; et al. Potential of coconut oil and medium chain triglycerides in the prevention and treatment of Alzheimer's disease. Mech. Ageing Dev. 2020, 186, 111209. [CrossRef] [PubMed]

37. Henderson, S.T.; Vogel, J.L.; Barr, L.J.; Garvin, F.; Jones, J.J.; Costantini, L.C. Study of the ketogenic agent AC-1202 in mild to moderate Alzheimer's disease: A randomized, double-blind, placebo-controlled, multicenter trial. Nutr. Metab. $2009,6,31$. [CrossRef] [PubMed]

38. Rebello, C.J.; Keller, J.N.; Liu, A.G.; Johnson, W.D.; Greenway, F.L. Pilot feasibility and safety study examining the effect of medium chain triglyceride supplementation in subjects with mild cognitive impairment: A randomized controlled trial. $B B A$ Clin. 2015, 3, 123-125. [CrossRef]

39. Reger, M.A.; Henderson, S.T.; Hale, C.; Cholerton, B.; Baker, L.D.; Watson, G.S.; Hyde, K.; Chapman, D.; Craft, S. Effects of beta-hydroxybutyrate on cognition in memory-impaired adults. Neurobiol. Aging 2004, 25, 311-314. [CrossRef]

40. Taylor, M.K.; Sullivan, D.K.; Mahnken, J.D.; Burns, J.M.; Swerdlow, R.H. Feasibility and efficacy data from a ketogenic diet intervention in Alzheimer's disease. Alzheimers Dement. Transl. Res. Clin. Interv. 2018, 4, 28-36. [CrossRef]

41. Ota, M.; Matsuo, J.; Ishida, I.; Takano, H.; Yokoi, Y.; Hori, H.; Yoshida, S.; Ashida, K.; Nakamura, K.; Takahashi, T.; et al. Effects of a medium-chain triglyceride-based ketogenic formula on cognitive function in patients with mild-to-moderate Alzheimer's disease. Neurosci. Lett. 2019, 690, 232-236. [CrossRef]

42. Hu Yang, I.; De la Rubia Orti, J.E.; Selvi Sabater, P.; Sancho Castillo, S.; Rochina, M.J.; Manresa Ramon, N.; Montoya-Castilla, I. Coconut Oil: Non-Alternative Drug Treatment against Alzheimer S Disease. Nutr. Hosp. 2015, 32, 2822-2827. [CrossRef]

43. de la Rubia Orti, J.E.; Garcia-Pardo, M.P.; Drehmer, E.; Sancho Cantus, D.; Julian Rochina, M.; Aguilar, M.A.; Hu Yang, I. Improvement of Main Cognitive Functions in Patients with Alzheimer's Disease after Treatment with Coconut Oil Enriched Mediterranean Diet: A Pilot Study. J. Alzheimers Dis. 2018, 65, 577-587. [CrossRef]

44. Mett, J.; Muller, U. The medium-chain fatty acid decanoic acid reduces oxidative stress levels in neuroblastoma cells. Sci. Rep. 2021, 11, 6135. [CrossRef]

45. Grimm, M.O.; Stahlmann, C.P.; Mett, J.; Haupenthal, V.J.; Zimmer, V.C.; Lehmann, J.; Hundsdorfer, B.; Endres, K.; Grimm, H.S.; Hartmann, T. Vitamin E: Curse or Benefit in Alzheimer's Disease? A Systematic Investigation of the Impact of alpha-, gammaand delta-Tocopherol on Ass Generation and Degradation in Neuroblastoma Cells. J. Nutr. Health Aging 2015, 19, $646-656$. [CrossRef]

46. Grimm, M.O.; Haupenthal, V.J.; Rothhaar, T.L.; Zimmer, V.C.; Grosgen, S.; Hundsdorfer, B.; Lehmann, J.; Grimm, H.S.; Hartmann, T. Effect of Different Phospholipids on alpha-Secretase Activity in the Non-Amyloidogenic Pathway of Alzheimer's Disease. Int. J. Mol. Sci. 2013, 14, 5879-5898. [CrossRef]

47. Jankowsky, J.L.; Fadale, D.J.; Anderson, J.; Xu, G.M.; Gonzales, V.; Jenkins, N.A.; Copeland, N.G.; Lee, M.K.; Younkin, L.H.; Wagner, S.L.; et al. Mutant presenilins specifically elevate the levels of the 42 residue beta-amyloid peptide in vivo: Evidence for augmentation of a 42-specific gamma secretase. Hum. Mol. Genet. 2004, 13, 159-170. [CrossRef] [PubMed]

48. Kumar, P.; Nagarajan, A.; Uchil, P.D. Analysis of Cell Viability by the Lactate Dehydrogenase Assay. Cold Spring Harb. Protoc. 2018, 2018, pdb.prot095497. [CrossRef] 
49. Crowley, L.C.; Scott, A.P.; Marfell, B.J.; Boughaba, J.A.; Chojnowski, G.; Waterhouse, N.J. Measuring Cell Death by Propidium Iodide Uptake and Flow Cytometry. Cold Spring Harb. Protoc. 2016, 2016, pdb-prot087163. [CrossRef]

50. Livak, K.J.; Schmittgen, T.D. Analysis of relative gene expression data using real-time quantitative PCR and the 2(-Delta Delta C(T)) Method. Methods 2001, 25, 402-408. [CrossRef] [PubMed]

51. Smith, P.K.; Krohn, R.I.; Hermanson, G.T.; Mallia, A.K.; Gartner, F.H.; Provenzano, M.D.; Fujimoto, E.K.; Goeke, N.M.; Olson, B.J.; Klenk, D.C. Measurement of protein using bicinchoninic acid. Anal. Biochem. 1985, 150, 76-85. [CrossRef]

52. Janitschke, D.; Nelke, C.; Lauer, A.A.; Regner, L.; Winkler, J.; Thiel, A.; Grimm, H.S.; Hartmann, T.; Grimm, M.O.W. Effect of Caffeine and Other Methylxanthines on Abeta-Homeostasis in SH-SY5Y Cells. Biomolecules 2019, 9, 689. [CrossRef] [PubMed]

53. Gorr, S.U.; Moore, Y.R. Sorting of a constitutive secretory protein to the regulated secretory pathway of exocrine cells. Biochem. Biophys. Res. Commun. 1999, 257, 545-548. [CrossRef]

54. Grimm, M.O.; Grosgen, S.; Riemenschneider, M.; Tanila, H.; Grimm, H.S.; Hartmann, T. From brain to food: Analysis of phosphatidylcholins, lyso-phosphatidylcholins and phosphatidylcholin-plasmalogens derivates in Alzheimer's disease human post mortem brains and mice model via mass spectrometry. J. Chromatogr. A 2011, 1218, 7713-7722. [CrossRef]

55. Sastry, P.S. Lipids of nervous tissue: Composition and metabolism. Prog. Lipid Res. 1985, 24, 69-176. [CrossRef]

56. Liberato, M.V.; Nascimento, A.S.; Ayers, S.D.; Lin, J.Z.; Cvoro, A.; Silveira, R.L.; Martinez, L.; Souza, P.C.; Saidemberg, D.; Deng, T.; et al. Medium chain fatty acids are selective peroxisome proliferator activated receptor (PPAR) gamma activators and pan-PPAR partial agonists. PLoS ONE 2012, 7, e36297. [CrossRef]

57. Du, J.; Zhang, L.; Liu, S.; Zhang, C.; Huang, X.; Li, J.; Zhao, N.; Wang, Z. PPARgamma transcriptionally regulates the expression of insulin-degrading enzyme in primary neurons. Biochem. Biophys. Res. Commun. 2009, 383, 485-490. [CrossRef]

58. Kadowaki, H.; Grant, M.A. Relationship of membrane phospholipid composition, lactosylceramide molecular species, and the specificity of CMP-N-acetylneuraminate:lactosylceramide alpha 2,3-sialyltransferase to the molecular species composition of GM3 ganglioside. J. Lipid Res. 1995, 36, 1274-1282. [CrossRef]

59. Werlein, A.; Peters, A.; Ngoune, R.; Winkler, K.; Putz, G. Interference of phosphatidylcholines with in-vitro cell proliferation-No flock without black sheep. Biochim. Biophys. Acta 2015, 1848, 1599-1608. [CrossRef]

60. Llorente, A.; van Deurs, B.; Sandvig, K. Cholesterol regulates prostasome release from secretory lysosomes in PC-3 human prostate cancer cells. Eur. J. Cell Biol. 2007, 86, 405-415. [CrossRef]

61. Phuyal, S.; Hessvik, N.P.; Skotland, T.; Sandvig, K.; Llorente, A. Regulation of exosome release by glycosphingolipids and flotillins. FEBS J. 2014, 281, 2214-2227. [CrossRef] [PubMed]

62. Record, M.; Carayon, K.; Poirot, M.; Silvente-Poirot, S. Exosomes as new vesicular lipid transporters involved in cell-cell communication and various pathophysiologies. Biochim. Biophys. Acta 2014, 1841, 108-120. [CrossRef] [PubMed]

63. Trajkovic, K.; Hsu, C.; Chiantia, S.; Rajendran, L.; Wenzel, D.; Wieland, F.; Schwille, P.; Brugger, B.; Simons, M. Ceramide triggers budding of exosome vesicles into multivesicular endosomes. Science 2008, 319, 1244-1247. [CrossRef]

64. Song, E.S.; Rodgers, D.W.; Hersh, L.B. Insulin-degrading enzyme is not secreted from cultured cells. Sci. Rep. 2018, 8, 2335. [CrossRef]

65. Leissring, M.A. Insulin-Degrading Enzyme: Paradoxes and Possibilities. Cells 2021, 10, 2445. [CrossRef]

66. DeMattos, R.B.; Bales, K.R.; Cummins, D.J.; Dodart, J.C.; Paul, S.M.; Holtzman, D.M. Peripheral anti-A beta antibody alters CNS and plasma A beta clearance and decreases brain A beta burden in a mouse model of Alzheimer's disease. Proc. Natl. Acad. Sci. USA 2001, 98, 8850-8855. [CrossRef]

67. Zhang, Y.; Lee, D.H. Sink hypothesis and therapeutic strategies for attenuating Abeta levels. Neuroscientist 2011, 17, 163-173. [CrossRef]

68. Spector, R. Fatty acid transport through the blood-brain barrier. J. Neurochem. 1988, 50, 639-643. [CrossRef] [PubMed]

69. Augustin, K.; Khabbush, A.; Williams, S.; Eaton, S.; Orford, M.; Cross, J.H.; Heales, S.J.R.; Walker, M.C.; Williams, R.S.B. Mechanisms of action for the medium-chain triglyceride ketogenic diet in neurological and metabolic disorders. Lancet Neurol. 2018, 17, 84-93. [CrossRef]

70. Studzinski, C.M.; MacKay, W.A.; Beckett, T.L.; Henderson, S.T.; Murphy, M.P.; Sullivan, P.G.; Burnham, W.M. Induction of ketosis may improve mitochondrial function and decrease steady-state amyloid-beta precursor protein (APP) levels in the aged dog. Brain Res. 2008, 1226, 209-217. [CrossRef] [PubMed]

71. Maianti, J.P.; Tan, G.A.; Vetere, A.; Welsh, A.J.; Wagner, B.K.; Seeliger, M.A.; Liu, D.R. Substrate-selective inhibitors that reprogram the activity of insulin-degrading enzyme. Nat. Chem. Biol. 2019, 15, 565-574. [CrossRef]

72. Tamaki, C.; Ohtsuki, S.; Terasaki, T. Insulin facilitates the hepatic clearance of plasma amyloid beta-peptide (1 40) by intracellular translocation of low-density lipoprotein receptor-related protein 1 (LRP-1) to the plasma membrane in hepatocytes. Mol. Pharmacol. 2007, 72, 850-855. [CrossRef] [PubMed]

73. Henderson, S.T.; Poirier, J. Pharmacogenetic analysis of the effects of polymorphisms in APOE, IDE and IL1B on a ketone body based therapeutic on cognition in mild to moderate Alzheimer's disease; a randomized, double-blind, placebo-controlled study. BMC Med. Genet. 2011, 12, 137. [CrossRef] [PubMed] 